\title{
Structural characterization and Biological Activity of Sulfolipids from selected Marine Algae
}

\author{
By F.K. El Baz ${ }^{1}$, G.S. El Baroty ${ }^{2}$, H.H. Abd El Baky ${ }^{1,}$, O.I. Abd El-Salam ${ }^{3}$ and E.A. Ibrahim ${ }^{1}$
}

\author{
${ }^{1}$ Plant Biochemistry Department, National Research Centre, Dokki, Cairo, Egypt \\ ${ }^{2}$ Biochemistry Department of, Faculty of Agriculture, Cairo University, Cairo, Egypt \\ ${ }^{3}$ Applied Organic Chemistry Department, National Research Centre, Dokki, Cairo, Egypt \\ Corresponding author: abdelbakyh@ hotmail.com
}

\section{RESUMEN}

\section{Caracterización estructural y actividad biológica de sulfolípidos de algas marinas seleccionadas}

Se separaron diferentes clases sulfolípidos (SL) a partir de los lípidos totales de cinco especies de algas marinas: una especie de Chlorophyta (Ulva fasciata), dos especies de Phaeophyta (Dilophys fasciola, Taonia atomaria) y dos especies de Rhodophyta (Laurencia popillose, Galaxoura cylindriea) que se purificaron mediante cromatografía en columna de DEAE-celulosa. Los components de SLs fueron identificados por IR, cromatografía de gases MS/MS y cromatografía líquida MS/ MS. Los contenidos de SL en relación al total de lípidos varió de $1,25 \%$ (en L. papilosa) al $11,82 \%$ (en D. fasciola). Sin embargo, no hay diferencias significativas en el contenido de sulfato observado entre todas estas especies de algas (desde 0,13 hasta $0,21 \%$ ). Todos los SL se caracterizaron por un alto contenido de ácido palmítico (C16:0), que osciló entre $30,91 \%$ en G. cylindriea a $63,11 \%$ en T. atomatia. Sulfoquinovosyl-di-acilglicerol y acilglicerol sulfoquinovosyl fueron identificados como los principales constituyentes de los sulfolípidos de estas algas.

Los sulfolípidos de las diferentes especies de algas estudiadas mostraron una notable actividad antiviral contra el virus del herpes simple tipo 1 (VHS-1) con una IC50 que osciló entre 18,75 y $70.2 \mathrm{~g} \mathrm{~mL}^{-1}$. Por otra parte, los sulfolípidos de estas algas inhibieron el crecimiento de células tumorales de mama y células de cáncer de hígado humano con valores de IC50 que van desde 0,40 hasta $0,67 \mathrm{~g} \mathrm{~mL}^{-1}$ para las células de adenocarcinoma de mama humano (MCF7).

PALABRAS CLAVE: Algas marinas contra el cáncer - Antibacterianas - Antivirales - Células - HepG2 - HSV-1 - MCF7 - Sulfolípidos.

\section{SUMMARY}

Structural characterization and Biological Activity of Sulfolipids from some Marine Algae

The sulfolipid classes (SLs) in the total lipids of five species of marine algae, two species of Rhodophyta (Laurencia popillose, Galaxoura cylindriea), one species of Chlorophyta (Ulva fasciata), and two species of Phaeophyta (Dilophys fasciola, Taonia atomaria) were separated and purified on DEAE-cellulose column chromatography. The SLs component was identified by IR, gas chromatography MS/MS and liquid chromatography MS/MS. The level of SLs contents va- ried from $1.25 \%$ (in L. papillose) to $11.82 \%$ (in D. fasciola) of the total lipid contents. However, no significant differences in sulfate content $(0.13-0.21 \%)$ were observed among all these algae species. All SLs were characterized by high contents of palmitic acid $\left(\mathrm{C}_{16: 0}\right)$, which ranged from $30.91 \%$ in $G$. cylindriea to $63.11 \%$ in $T$. atomatia. The main constitutes of algal sulfolipids were identified as sulfoquinovosyl-di-acylglycerol and sulfoquinovosyl acylglycerol.

The sulfolipids of different algal species exhibited remarkable antiviral activity against herps simplex virus type 1 (HSV-1) with an $\mathrm{IC}_{50}$ ranging from 18.75 to $70.2 \mu \mathrm{g} \mathrm{mL}$. Moreover, algal sulfolipid inhibited the growth of the tumor cells of breast and liver human cancer cells with $\mathrm{IC}_{50}$ values ranging from 0.40 to $0.67 \mu \mathrm{g} \mathrm{mL}^{-1}$ for human breast adenocarcinoma cells (MCF7)

KEY-WORDS: Antibacterial - Anticancer - Antiviral Cells - HepG2 - HSV-1 - Marine algae - MCF7 - Sulfolipids.

\section{INTRODUCTION}

Glycolipids (GL), sulfolipids (SL) and phospholipids $(\mathrm{PL})$ are usually present in all photosynthetic membranes in plants, algae and various bacteria. However, Sulfolipids (SLs) represent up to $29 \%$ of total lipid and have been regarded as predominant lipid components in both prokaryotic and eukaryotic organisms (Norman et al., 1996; Benning and Somerville, 1992). SLs are located in the thylakoid membrane as an important component to preserve the membrane's structure and function. Recently, lipid constituents have been recognized as potentially important factors in the processes of signal transduction and endomembrane transport (Simons and Toomre 2000). However, algae represent valuable sources of a wide spectrum of complex lipids, and their components have promising potential applications especially in the food, cosmetic, and pharmaceutical industries (Hossain et al., 2005). The various biological actions of SLs include: inhibitory effects on DNA polymerase and viral reverse transcriptase, antitumor, anti-inflammatory, and inhibition and promotion of cell growth (Mizushina et al., 1998; Liptak et al., 2004; Maeda et al., 2008; Naumann, 2009). Several reports have indicated that SLs compounds isolated from 
different algae species inhibited the growth of several viruses (such as HIV, HSV-1 and the AIDS virus) as well as cancer types (Gustafson et al., 1989; Xue et al., 2002; Chirasuwan et al., 2009). For instance, the sulfolipids of $S$. horneri were found to possess a potent anticancer activity against colon cancer cells (Caco-22 ceils) (Hossain et al., 2005). In addition, the SLs of Porphyridium cruentum showed inhibitory effects on human colon (DLD-1), breast (MCF-7), prostate adenocarcinoma (PC-3) and malignant melanoma (M4 Beu) cancer cells (Bergé et al., 2002).

The aim of the present work is to characterize the chemical structure and evaluate the biological activity of the sulfolipids of some marine algae collected from the Red and Mediterranean seas in Egypt.

\section{MATERIALS AND METHODS}

\subsection{Collection of marine algal samples}

Samples of Laurencia popillose and Galaxoura cylindriea were collected from the Red Sea (Faied and Ein Al-Sokhna at Suez gulf canal). Ulva fasciata and Taonia atomaria were collected from the Mediterranean Sea at (Abu-Qir city) Alexandria Governmate and Dilophys fasciola from (Matroh city) Marsa Matrouh Government. All algal samples were washed several times with tap water and then left to air dry. Samples of $500 \mathrm{~g}$ were ground and stored in brown glass containers at room temperature for further analysis.

\subsection{Identification of marine algae species}

After preparation of herbarium specimens of the algae species, they were identified by Dr. Rauhaiya Abdul-Latif, Professor of Botany, Department of Botany, Faculty of Science, Al-Azhar University.

\subsection{Extraction and determination of total lipid}

The total lipids of marine algae $(10 \mathrm{~g})$ were extracted with $100 \mathrm{~mL}$ of the mixture: methanol: chloroform (2:1, v/v) (Roughan and Bratt, 1968). After filtration, the mixture was evaporated at $40^{\circ} \mathrm{C}$ to a minimum volume $(15 \mathrm{~mL})$ and dried under $\mathrm{N}_{2}$. Then, the total lipid contents were determined by weight.

\subsection{Isolation and determination of algal sulfolipids}

The sulfolipids were separated from the total lipid extracts using diethylaminoethyl-cellulose (DEAEcellulose) column chromatography $(0.6 \times 6 \mathrm{~cm}$, i.d), then eluted with a $21.5 \mathrm{~mL}$ mixture of chloroform/ methanol (20 mL; 6:4, v/v) and concentrated $\mathrm{NH}_{3}$ (1.5 mL) (Roughan and Bartt 1968). The mixture, which contained purified sulfolipids, was dried at $40^{\circ} \mathrm{C}$, under $\mathrm{N}_{2}$ then the total sulfolipids were calculated by weight.

\subsection{Identification of algal sulfolipids}

\subsubsection{Determination of total sulfate of algal sulfolipids}

The sulfate content of algal sulfolipids was determined using a sodium rhodizonate reagent, which in the presence of barium forms a red compound. The reduction of color intensity indicates the quantity of sulfate present in the sample. A standard calibration curve was prepared using sodium sulfate $\left(\mathrm{Na}_{2} \mathrm{SO}_{4}\right)$, scaled for 1.0 $12.0 \mu \mathrm{g}$ sulfate (Terho and Hartiala, 1971).

\subsubsection{Identification of algal sulfolipid fatty acids}

The algal sulfolipids were subjected to direct transmethylation in 1.5\% sulfuric acid:methanol at $95^{\circ} \mathrm{C}$ for $2 \mathrm{~h}$ (Luddy et al., 1960). Fatty acid methyl esters were analyzed by gas chromatography (Perkin Elmer Autosystem XL) equipped with a flame ionization detector and fused silica capillary column (DB-5 (American) $60 \mathrm{~m} \times 0.32 \mathrm{~mm}$, i.d.) with a film thickness of $0.25 / 25 \mu \mathrm{m}$. The column temperature was initially $150^{\circ} \mathrm{C}$ and was then gradually increased at rate of $3^{\circ} \mathrm{C} \mathrm{min}^{-1}$ up to $250^{\circ} \mathrm{C}$. The injector and detector temperatures were $230^{\circ} \mathrm{C}$ and $250^{\circ} \mathrm{C}$, respectively. Helium was used as the carrier gas (at $1 \mathrm{~mL} \mathrm{~min}^{-1}$ ). The split ratio was $1 / 100$. The fatty acids were identified by comparison between the retention times of the samples and those of methyl fatty acid standard mixtures ( Sigma, > 99\% purity by GLC).

\subsubsection{Identification of function group of marine algal sulfolipids using IR}

The IR spectra of algal sulfolipid samples were recorded on a JASCO FT/IR 6100A spectrometer in the wave number range $4000-400 \mathrm{~cm}^{-1}$, according to the $\mathrm{KBr}$ disk method.

\subsubsection{LC-MS-MS analysis of algal sulfolipids}

An aliquot of sulfolipid fraction was analyzed by LC-MS-MS (LCQ Advantage Max, Thermo Finnegan, USA) using a triple mass spectrometer operating in positive electro spray ionization (ESI). The heated capillary and voltage were maintained at $255^{\circ} \mathrm{C}$ and $4.5 \mathrm{KeV}$, respectively. The full scans of mass spectra of the sulfolipids were carried out from m/z 500 to 2000 using $500 \mathrm{~ms}$ for the collection of ion in the trap. MS/MS was used to break down the most abundant $[\mathrm{M}+\mathrm{H}]^{+}$ion from MS with depended collection induced dissociation (CID) (Pons et al., 2002).

\subsubsection{Identification of algal sulfolipids using $\mathrm{GC}-\mathrm{MS}$}

Sulfolipids were identified using GC-MS (Chrompack France, Les Ullis, France) equipped 
with a $0.25 \mu \mathrm{m}$ film phase and fused CP-Sil5 CB Low bleed-MS capillary column $(25 \mathrm{~m} \times 0.32 \mathrm{~mm})$. The temperature of the injector was $280^{\circ} \mathrm{C}$. Sulfolipids were analyzed using the following temperature program: $90^{\circ} \mathrm{C}$ for 3 min then gradually increased at the ratio of $5^{\circ} \mathrm{C} \min ^{-1}$ until $260^{\circ} \mathrm{C}$. The analyses were performed in the $\mathrm{El}$ mode (ionization energy $70 \mathrm{eV}$; source temperature $150^{\circ} \mathrm{C}$ ) (Pons et al., 2002)

\subsection{Biological evaluation of marine algal sulfolipids}

\subsubsection{Antiviral activity of algal sulfolipids}

Preparation of the algal extract for bioassay. A stock solution of algal SLs was freshly prepared by dissolving $100 \mathrm{mg}$ of sulfolipid fraction in $10 \mathrm{~mL}$ of dimethyl sulfoxide (DMSO) in water $(9: 1, \mathrm{v} / \mathrm{v})$ and kept at $4{ }^{\circ} \mathrm{C}$ until use; appropriate dilutions of the solution were used in each assay. All the tests were carried out in three independent assays, and the means were applied.

Antiviral screening of algal sulfolipids. Algal SLs were evaluated for antiviral activity against herps simplex virus type- 1 (HSV-1). The virus was obtained from the Virology Laboratory, Water Pollution Research Dept., National Research Center (NRC), Egypt. The virus was propagated in viro cell cultures. The Inhibition \% of the virus was calculated as plaque reduction as a result of being subjected to a given extract (Tebas et al., 1995).

\subsubsection{Antitumor activity of algal sulfolipids}

The potential antitumor activity of algal sulfolipids was tested using the method of Skehan et al. (1990). Human hepato cellular carcinoma cells (Hep G2) and breast adenocarcinoma cells (MCF-7) were plated on 96 multi-well plates for $24 \mathrm{~h}$ before treatment with the algal sulfolipid to allow for the attachment of cells to the well of the plate. Sulfolipids and antitumor reference drugs (Novantron) were added at serial concentrations to cell monolayers. After incubation for $48 \mathrm{~h}$ at $37^{\circ} \mathrm{C}$ in an atmosphere of $5 \% \mathrm{CO}_{2}$, the cytotoxicity was determined spectrophotometrically by measuring the developed color at $570 \mathrm{~nm}$ by the ELISA reader (Tecan Sunrise absorbance reader (No. 3008746), software Magllan V.4, Germany).

\subsubsection{Antimicrobial activity of algal sulfolipids}

The antimicrobial activities were determined by the conventional agar diffusion assay (Greenwood, 1983) using one gram positive (Bacillus subtilis NRRL B-94) one gram negative (Escherichia coli NRRL B-3703) bacteria, fungi (Aspergillus niger NRRL 313), and yeast (Candida albicans NRRL 477). The microbial growth inhibition zone was measured after incubation at $30 \mathrm{C}$ by the appearance of a clear, microbial free inhibition zone, beginning within $24 \mathrm{~h}$ for yeast, $24-48 \mathrm{~h}$ for bacteria and 72-96 $\mathrm{h}$ for fungus. The most active sulfolipid fractions were tested for their MIC according to Hammer et al., (1999). MIC was determined as the lowest concentration of sulfolipid fractions inhibiting the visible growth of each organism on the agar plate.

\subsection{Statistical analysis}

Data were statistically analyzed through the analysis of variance (ANOVA) and Duncan's test and the $P>0.01$ probability level was applied (Gomes and Gomes, 1984)

\section{RESULTS AND DISCUSSION}

\subsection{Marine algal total lipid contents}

The total lipid contents (TL) of marine algae ranged from 0.09 to $2.35 \%$ (Table 1 ). U. fasciata $(2.55 \%)$ had the highest TL content followed by D. fasciola $(1.11 \%)$, whereas the lowest level was found in G. cylindriea $(0.09 \%)$ followed by T. atomaria $(0.66 \%)$ and $L$. popillose $(0.88 \%)$. However, the concentrations of TL in the tested algae species were within the ranges (1.0 $5.0 \%$ ) reported in the literature for several algae species (Matanjun et al., 2009; Manivannan et al., 2008). For instance, the TL contents in 12 species of marine algae belong to 3 families from

Table 1

Total lipid, total sulfolipid contents and sulfate contents of some marine algae

\begin{tabular}{lccc}
\hline \multicolumn{1}{c}{ Algae species } & $\begin{array}{c}\text { Total lipid } \\
\text { Content \% }\end{array}$ & $\begin{array}{c}\text { Total sulfolipid } \\
\text { (\% of total lipid) }\end{array}$ & Sulfate \% \\
\hline U. fasciata & $2.35^{\mathrm{d}}$ & 3.60 & $0.13^{\mathrm{a}}$ \\
T. atomaria & $0.66^{\mathrm{b}}$ & 4.50 & $0.16^{\mathrm{a}}$ \\
D. fasciola & $1.11^{\mathrm{a}}$ & 11.80 & $0.21^{\mathrm{a}}$ \\
L. papillose & $0.81^{\mathrm{c}}$ & 1.25 & $0.16^{\mathrm{a}}$ \\
G. cylindriea & $0.09^{\mathrm{a}}$ & 10.00 & $0.17^{\mathrm{a}}$ \\
LSD & 0.09 & & 0.07 \\
\hline
\end{tabular}

The mean $(\mathrm{n}=3)$ difference is significant at $P \leq 0.01$. 
the Chlorophyceaean (4 species), Phaeophyceae (5 species) and Rhodophyceae (3 species) and ranged from $1.33 \pm 0.20 \%$ to $4.60 \pm 0.17 \%$ (Manivannan et al. 2008). In general, the total lipid contents varied among alga species depending on species, genetic origin, climate and the geography of the development of the algae (Araki et al. 1990).

\subsection{Algal total sulfolipid contents}

The sulfolipid fractions of five macroalgal lipids are illustrated in Table (1). The sulfolipid fraction content ranged from 1.25 to $11.80 \%$ of the total lipids. The highest sulfolipid content was found in $D$. fasciola (11.80\%) followed by G. cylindriea (10.00\%). The lowest sulfolipid fractions were detected in $T$. atomaria (4.50\%), U. fasciata (3.60\%) and L. papillose (1.25\%).

\subsubsection{Sulfate content of marine algal sulfolipids (SLS)}

The sulfate content among the algae sulfolipids ranged between 0.13 and $0.21 \%$. The highest sulfate content was found in $D$. fasciola $(0.21 \%)$ followed by $G$. cylindriea $(0.17 \%), T$. atomaria $(0.16 \%), L$. papillose $(0.16 \%)$ and U.fasciata $(0.13 \%)$. These results agree with those obtained by Sanina et al. (2004) in which the sulfolipid contents of the total lipids in A. tobuchiensis (Rodophyta), L. japonica and $S$. pallidum (Phaeophyta), U. fenestrata (Chlorophyta) and Z. marina (Embriophyta) were $10.0 \%, 15.0 \%, 7.1 \%, 9.7 \%$ and $6.2 \%$, respectively. In addition, these results are in accordance with those of Gerasimenko et al. (2010), who stated that the sulfolipid contents of juvenile and adult brown algae Costaria costata ranged from 0.4 to $10.6 \%$ of the total lipids.

\subsubsection{Fatty acid compositions of marine algal sulfolipids}

The fatty acid compositions of the algal sulfolipid fraction are presented in Table 2. All algal SLs have high contents of plamitic acid $\left(\mathrm{C}_{16: 0}\right)$, ranging from $30.9 \%$ (G. cylindriea) to $63.1 \%$ (T. atomaria); while $\mathrm{C}_{22: 5}$ was detected in $T$. atomaria $(13.8 \%)$, G. cylindriea (13.8\%) and L. papillose (10.80\%). Margaric acid $\left(\mathrm{C}_{1700}\right)$ was identified as the main fatty acid in the SLs of U. fasciata (21.6\%) and L. papillose (12.9\%). A remarkable content of arachidonic acid $\left(\mathrm{C}_{20: 4}\right)$ was detected in $G$. cylindriea $(37.4 \%)$. Oleic acid $\left(C_{18: 1}\right)$ and linoleic $\left(C_{18: 2}\right)$ were also found in considerable amounts at $11.4 \%$ in sulfolipid of $U$. fasciata and 27.1 and $10.7 \%$ in the sulfolipid fraction of $D$. fasciola and $L$. papillose, respectively. These results reveal that fatty acid composition differed significantly among all the algae species. The FA composition of the sulfolipid fraction is similar to those previously reported for green, brown and red algae (Sanina et al., 2004). Similar results were obtained by Araki et al., (1989), who found that the sulfoquinovosyl diacylglycerols (SQDG) of $G$. verrucosa were characterized by high levels of $C_{16: 0}$ and $\mathrm{C}_{20: 4 \omega 6}$ fatty acids. $P$. incisa sulfolipid (SQDG)

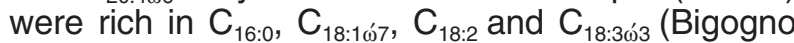
et al., 2002). Xue et al. (2002) found that the main fatty acids of Spirulina platensis SQDG were $C_{16: 0}$, and $\mathrm{C}_{18: 2 n-6 . .}$ The major fatty acids of sulfoquinovosyldi-acylglyceride in Phaeophyta, Chlorophyta and Rhodophyta were saturated and monounsaturated

Table 2

Fatty acid composition of marine algal sulfolipids

\begin{tabular}{|c|c|c|c|c|c|}
\hline \multirow{3}{*}{ Fatty acids } & \multicolumn{5}{|c|}{ Algae strains } \\
\hline & \multicolumn{3}{|c|}{ Mediterranean sea } & \multicolumn{2}{|c|}{ Red sea } \\
\hline & U. fasciata & T. atomaria & D. fasciola & L. papillose & G. cylindriea \\
\hline$C_{14: 0}$ & 0.90 & 10.9 & 3.9 & 4.7 & 2.8 \\
\hline$C_{16: 0}$ & 49.9 & 63.1 & 57.7 & 34.5 & 30.9 \\
\hline$C_{16: 1}$ & - & - & 1.2 & 2.1 & 1.2 \\
\hline$C_{17: 0}$ & 21.5 & 4.51 & 0.78 & 12.8 & 1.0 \\
\hline$C_{18: 0}$ & 2.8 & 4.0 & 1.9 & 6.4 & 4.0 \\
\hline $\mathrm{C}_{18: 1}$ & 11.3 & 3.0 & 3.1 & 6.4 & 3.1 \\
\hline$C_{18: 2}$ & 2.4 & - & 27.1 & 10.7 & 4.4 \\
\hline$C_{20: 3}$ & 1.7 & 0.5 & 0.1 & 0.75 & 1.2 \\
\hline $\mathrm{C}_{20: 4}$ & 1.3 & - & - & 1.6 & 37.4 \\
\hline $\mathrm{C}_{22: 5}$ & 7.4 & 13.8 & 3.9 & 10.8 & 13.8 \\
\hline SFAs \% & 75.2 & 82.6 & 64.4 & 58.5 & 38.7 \\
\hline MUFAs \% & 11.3 & 3.0 & 4.3 & 8.5 & 4.4 \\
\hline PUFAs \% & 5.5 & 14.3 & 31.1 & 23.6 & 43.0 \\
\hline
\end{tabular}

FA, fatty acid; SFAs, saturated fatty acids; MUFAs, monounsaturated fatty acids; PUFAs, Polyunsaturated fatty acids. 
fatty acids except for SQDG from Chlorophyta ( $Z$. marina), which contained the highest contents of $\mathrm{C}_{18: 2 n-6}$ and $\mathrm{C}_{18: 3 n-3}$ acids (Khotimchenko, 2003). Hossain et al. (2005) found that the major fatty acids of SQDG from $S$. horneri (brown algae) were $\mathrm{C}_{16: 0}$, $\mathrm{C}_{18: 1}, \mathrm{C}_{18: 4}, \mathrm{C}_{20: 1}, \mathrm{C}_{20: 4}$, and $\mathrm{C}_{20: 5}$

\subsection{Proposed algal sulfolipid structures of bioactive constituents}

\subsubsection{IR analysis}

As illustrated in Figure 1, the infrared spectra of all algal sulfolipid fractions showed two characteristic absorption bands for sulpher-containing compounds. The first one appeared at $927 \mathrm{~cm}^{-1}$, indicating the presence of a strong dehydration of $\mathrm{SO}_{3}$ and the second was at $771 \mathrm{~cm}^{-1}$, indicating a symmetrical $\mathrm{C}-\mathrm{O}-\mathrm{S}$ associated with a $\mathrm{C}-\mathrm{O}-\mathrm{SO}_{3}$ group (Ermanno et al., 1994 and Ranjaniv and Steven 1995). Regarding other absorption bands, there were large amounts of $\mathrm{OH}$ stretching at $3400 \mathrm{~cm}^{-1}$, symmetric $\mathrm{CH}_{3}$ bending at $1380 \mathrm{~cm}^{-1}$ and $\mathrm{C}-\mathrm{H}$ stretching at $2930 \mathrm{~cm}^{-1}$.

\subsubsection{Identification of marine algal sulfolipid compounds by GG-MS and LC-MS/MS}

The proposed chemical structure of the active constituents of the algal sulfolipids was determined using GC-MS and LC-MS-MS. Several compounds of sulfolipids were separated from algae and two of them were identified by EI-MS and ESI/ MS fragmentations. The ESI/MS and El/ MS of the major component (compound 1) of sulfolipids consisted of molecular ion $[\mathrm{M}+\mathrm{H}]^{+}$at $m / z=820$ corresponding to the molecular formula of $\mathrm{C}_{43} \mathrm{H}_{78} \mathrm{O}_{12} \mathrm{~S}$ (Fig. 2 and 4a). The main fragmentations of compound 1 were the peak at $\mathrm{m} / \mathrm{z}=564.3$ (Fig. 2) and was due to the loss of fatty acyl (plamitic acid $\mathrm{C}_{16: 0}, \mathrm{~m} / \mathrm{z} 255.3$ ). The peak at $\mathrm{m} / \mathrm{z}=329$ was due to the loss of linoleic acid $\left(C_{18: 2}\right)$, which is characteristic for SQDG. The peak at $\mathrm{m} / \mathrm{z}=243$ was due to the loss of glycerol $(\mathrm{m} / \mathrm{z}=87)$. The fragmentation of compound 1 may result in sulfoquinovosyl-di-acylglycerol (Figure 4a).

The LC/MS/MS data revealed that the minor second compound was consistent with the

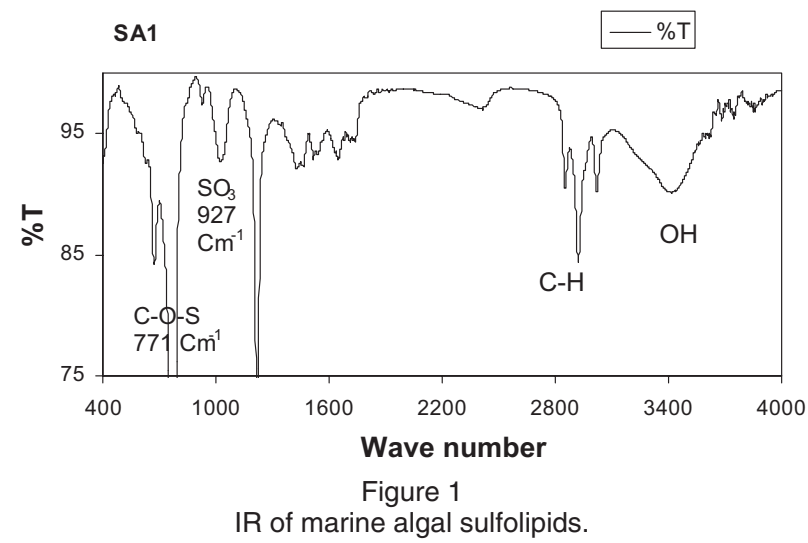

molecular ion $[\mathrm{M}+\mathrm{H}]^{+}$at $\mathrm{m} / \mathrm{z}=556.7$ (Figure 3 and $4 \mathrm{~b}$ ) corresponding to the molecular formula of $\mathrm{C}_{25} \mathrm{H}_{48} \mathrm{O}_{11} \mathrm{~S}$. The main fragmentations of SQMG were the peak at $\mathrm{m} / \mathrm{z}=293.71$ due to the loss of palmitic acid. The peak at $\mathrm{m} / \mathrm{z}=206.71$ was due to the loss of glycerol. The fragmentation of compound 2 may result in sulfoquinovosyl acylglycerol (SQMG, fig. 4b). Furthermore, this structure was provided by the GC-MS, and LC- MS/ MS fragmentation pattern and was similar to that reported by Keusgen et al., (1997).

The SQDG of the Chondria armata fraction was consistent with the sodiated molecular ion [M $+\mathrm{Na}]^{+}$at $m / z 629$, which have a mass difference corresponding to a likely loss of sulfonic acid $\left(\mathrm{SO}_{3} \mathrm{H}\right)$ and sodium salt $\left(\mathrm{SO}_{3} \mathrm{Na}\right)$, respectively. The product ion observed at $\mathrm{m} / \mathrm{z} 345$ appears to have originated by the loss of a fatty acyl side chain as corresponding acid (palmitic acid, $\mathrm{C}_{16: 0}$ ). Based on the fragmentation pattern, the sulfolipid with pseudo-molecular ion $[\mathrm{M}-\mathrm{H}+2 \mathrm{Na}]^{+}$at $\mathrm{m} / \mathrm{z}$ 601 was characterized as 2-O-palmitoyl-3-O-(6'sulfoquinovo-pyrano-syl)-glycerol (Al-Fadhli et al., 2006). SQDG structures gave three molecular ions by ESI/MS at $\mathrm{m} / \mathrm{z} 737.46,765.77$ and 793.77 . These ions showed that the glycerol moiety was esterified by the following combinations of fatty acids: $\left(\mathrm{C}_{14: 0}+\mathrm{C}_{16: 0}\right)$ giving $\mathrm{m} / \mathrm{z} 737.46 ;\left(\mathrm{C}_{14: 0}+\mathrm{C}_{16: 0}\right)$ giving $m / z 765.77$ and $\left(C_{14: 0}+C_{18: 0}\right.$ or $\left.C_{16: 0}+C_{16: 0}\right)$ giving $\mathrm{m} / \mathrm{z}$ 793.77. Tandem-MS gave fragments corresponding to sulfoquinovosyl $(\mathrm{m} / z 243.07$ and 225.44); and sulfoquinovose linked to glycerol $(\mathrm{m} / \mathrm{z}$ 283.35). Minor ions at $\mathrm{m} / \mathrm{z} 509.71$ and 537.83 are probably due to the respective loss of palmitic $\left(\mathrm{C}_{16: 0}\right)$ and myristic $\left(\mathrm{C}_{\text {14:0 }}\right)$ acids (De-Souza et al., 2007).

\subsection{Biological evaluation of sulfolipid fractions}

\subsubsection{Antiviral activity}

The antiviral activity of algal sulfolipids was evaluated according to the plaque reduction method and the results are summarized in Table 3. Algal sulfolipids showed high antiviral inhibitions against HSV-1, which ranged from 18.75 to $70.12 \%$. All algal sulfolipids had low virus inhibition at the concentration of $10.0 \mu \mathrm{g}$, while the highest inhibition HSV1 was observed at $20 \mu \mathrm{g} \mathrm{mL}^{-1}$ for $D$. fasciola $(70.12 \%)$. Thus, the sulfolipid fraction had dose-dependant antiviral activity. Among several antiviral available, acyclovir was used as a positive control in this study. The inhibitory effect of algae SLs $\left(\mathrm{IC}_{50}\right.$ ranged from 15.0 to $25.0 \mu \mathrm{g} \mathrm{mL}^{-1}$ ) was shown to be quite a bit more potent than that of acyclovir $\left(\mathrm{IC}_{50} 5.5 \mu \mathrm{g} \mathrm{mL}^{-1}\right)$. These results are in agreement with the results obtained by Chirasuwan et al., (2009) who found that sulphoquinovosyl-di-acylglycerol compounds extracted from Spriulina platensis have antiviral activity (HSV-1) in virus cells. Ohta et al., (1998) found that the new sulfolipid, 6-sulfo-alpha-D-quinovopyranosyl-1',2'diacylglycerol (SQDG) isolated from $G$. tenella (marine red alga) contains a potent inhibitor of eukaryotic DNA 


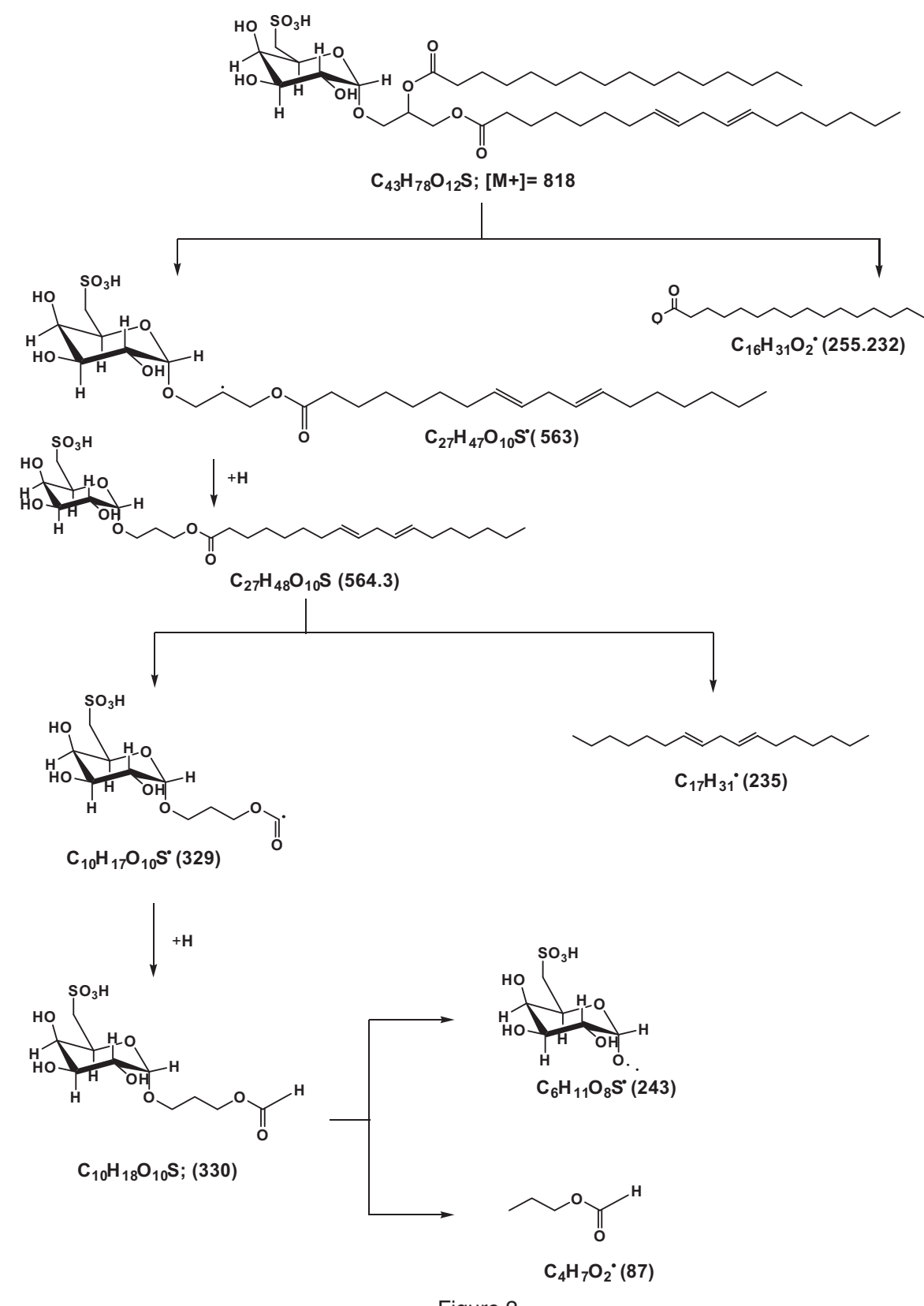

Fragmentation pattern of compound (1) sulfoquinovosyl-di-acylglycerol (SQDG) extracted from marine algal sulfolipids.

Table 3

Antiviral activity of some marine algae sulfolipids against HSV-1

\begin{tabular}{|c|c|c|}
\hline \multirow{2}{*}{ Marine algae strains } & \multicolumn{2}{|c|}{ Viral inhibition \% } \\
\hline & $10 \mu \mathrm{g} \mathrm{mL}^{-1}$ & $20 \mu \mathrm{gL}^{-1}$ \\
\hline U. fasciata & 18.75 & 46.87 \\
\hline T. atomaria & 43.75 & 56.25 \\
\hline L. papillose & 40.62 & 59.37 \\
\hline G. cylindriea & 45.87 & 59.37 \\
\hline D. fasciola & 46.87 & 70.12 \\
\hline $\begin{array}{l}\text { Acyclovir IC50 }\left(\mu \mathrm{g} \mathrm{mL}^{-1}\right) \\
\text { (reference drug) }\end{array}$ & \multicolumn{2}{|c|}{5.5} \\
\hline
\end{tabular}

polymerases and HIV-reverse transcriptase type 1 (Gustafson et al. 1998). The SQDG fraction of $S$. hofmanii contains (C18:2/C16:0) and showed a higher antiviral activity against $\mathrm{HCM}$-virus, with an $\mathrm{IC}_{50}$ of 19.0 $\mu \mathrm{g} \mathrm{mL} \mathrm{L}^{-1}$ (Naumann, 2009).

\subsubsection{Antitumor activity}

Antitumor activity against human breast carcinoma (MCF-7). The cytotoxic activities of five algal sulfolipid fractions were tested against MCF-7 and the results are illustrated in Table 4. All algal sulfolipid fractions showed high inhibition percentages $(\%)$ toward the MCF7 cell, which ranged from 66.24 to $94.19 \%$. L. popillose presented the highest antitumoral activity against the MCF-7 at all concentrations followed by T. atomaria, G. cylindriea and U. fasciata. In addition, 

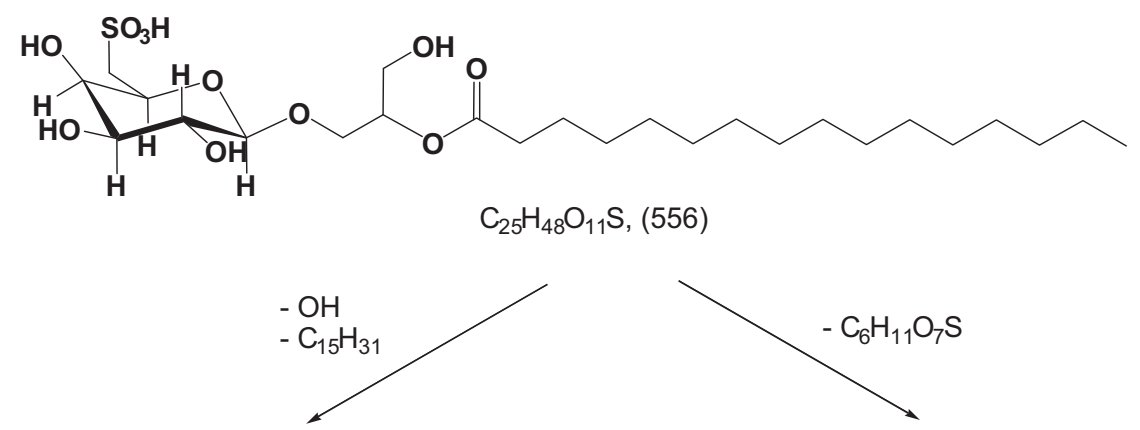<smiles>CC(COC1OC(=O)C2C(O)C(O)C(O)C1C2O)OC=O</smiles>

$\mathrm{C}_{10} \mathrm{H}_{17} \mathrm{O}_{10} \mathrm{~S},(329)$

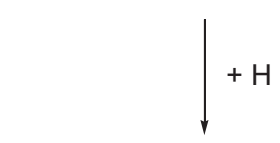<smiles>CC(COC1OC2C(O)C(O)C(O)C(O)C1C2O)OC(=O)O</smiles>

$\mathrm{C}_{10} \mathrm{H}_{18} \mathrm{O}_{10} \mathrm{~S},(330)$<smiles>O=C(CCCCCCCCCCO)OC(CO)CO</smiles><smiles>CCCCCCC(=O)OC(CO)CO</smiles>

$\mathrm{C}_{19} \mathrm{H}_{38} \mathrm{O}_{4},(330)$

Figure 3

Fragmentation pattern of compound (2) Sulfoquinovosyl -acylglycerol extracted from marine algal sulfolipids.

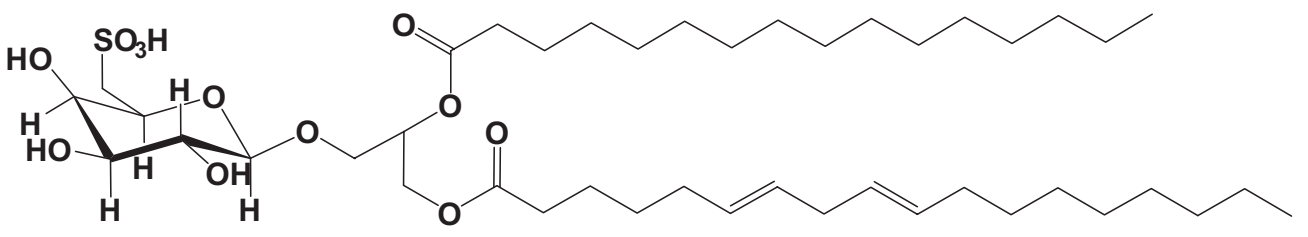

A<smiles>CCCCCCCCCCCCCCCC(=O)OC(CO)COC1OC2C(CO)C(O)C(O)C1C2OS(=O)(=O)O</smiles>

Figure 4

Suggested chemical structure of the different active compounds separated from the marine algal sulfolipids (SQDG). Compound A: sulfoquinovosyl-di-acylglycer. Compound B: sulfoquinovosyl-acylglycerol (SQMG).

all algal sulfolipid fractions showed high potential activities with an $\mathrm{IC}_{50}$ of $0.40-0.67 \mu \mathrm{g} \mathrm{mL}^{-1}$ against the MCF-7 cell (Table 5). In addition all algal sulfolipids have a significant antitumor activity compared to the reference antitumor drug novantron $\left(\mathrm{IC}_{50}=1.40 \mu \mathrm{g}\right.$ $\mathrm{mL}^{-1}$ ).

Antitumor activity against human hepato carcinoma (Hep G2). Table 4 illustrates that the algal sulfolipids of $T$. atomaria showed the highest inhibition activity (85.37\%) against HepG2 cells followed by $D$. fasciola $(80.29 \%), \quad L$. papillose $(79.89 \%)$ and U. fasciata (72.97\%). Therefore, all the algae sulfolipids showed potential antitumor activity against HEPG2 with $\mathrm{IC}_{50}$ values ranging from 0.60 to $2.75 \mu \mathrm{g} \mathrm{mL} \mathrm{m}^{-1}$ (Table 5). These results are in agreement with those obtained by 
Table 4.

Antitumor activity of algal sulfolipids against MCF7 and HepG2 cells after $48 \mathrm{~h}$ incubation

\begin{tabular}{|c|c|c|c|}
\hline \multirow{2}{*}{ Algae species } & \multirow{2}{*}{$\begin{array}{c}\text { Sulfolipids } \\
\text { Concentrations } \\
\left(\mu \mathrm{g} \mathrm{mL}^{-1}\right)\end{array}$} & \multicolumn{2}{|c|}{ Growth Inhibition \% } \\
\hline & & MCF7 Cell & HepG2 Cell \\
\hline \multirow{4}{*}{ U. fasciata } & 1.0 & $65.40^{\mathrm{a}}$ & $48.15^{\mathrm{a}}$ \\
\hline & 2.5 & $69.16^{\mathrm{bc}}$ & $54.39^{\mathrm{a}}$ \\
\hline & 5.0 & $76.27^{\mathrm{ab}}$ & $71.93^{\mathrm{a}}$ \\
\hline & 10.0 & $79.48^{c}$ & $72.97^{\mathrm{a}}$ \\
\hline \multirow{4}{*}{ T. atomaria } & 1.0 & $79.46^{\mathrm{a}}$ & $71.19^{\mathrm{a}}$ \\
\hline & 2.5 & $82.25^{\mathrm{a}}$ & $76.15^{\mathrm{a}}$ \\
\hline & 5.0 & $85.35^{\mathrm{a}}$ & $76.70^{\mathrm{a}}$ \\
\hline & 10.0 & $85.69^{a}$ & $85.67^{\mathrm{a}}$ \\
\hline \multirow{4}{*}{ D. fasciola } & 1.0 & $71.12^{\mathrm{a}}$ & $57.36^{\mathrm{a}}$ \\
\hline & 2.5 & $73.33^{\mathrm{a}}$ & $65.50^{\mathrm{a}}$ \\
\hline & 5.0 & $74.43^{\mathrm{a}}$ & $72.95^{\mathrm{a}}$ \\
\hline & 10.0 & $79.34^{\mathrm{a}}$ & $80.29^{a}$ \\
\hline \multirow{4}{*}{ L. papillose } & 1.0 & $76.93^{\mathrm{a}}$ & $37.35^{\mathrm{a}}$ \\
\hline & 2.5 & $90.66^{\mathrm{a}}$ & $44.85^{\mathrm{a}}$ \\
\hline & 5.0 & $92.48^{\mathrm{a}}$ & $71.56^{b}$ \\
\hline & 10.0 & $94.19^{a}$ & $79.89^{b}$ \\
\hline \multirow{4}{*}{ G. cylindriea } & 1.0 & $66.37^{\mathrm{a}}$ & $28.31^{\mathrm{a}}$ \\
\hline & 2.5 & $76.01^{b}$ & $42.21^{\mathrm{b}}$ \\
\hline & 5.0 & $77.30^{\mathrm{b}}$ & $69.06^{c}$ \\
\hline & 10.0 & $82.46^{\mathrm{c}}$ & $72.27^{\mathrm{c}}$ \\
\hline \multirow{4}{*}{$\begin{array}{l}\text { Novantron } \\
\text { (reference drug) }\end{array}$} & 1.0 & 42.73 & 26.1 \\
\hline & 2.5 & 52.81 & 42.27 \\
\hline & 5.0 & 52.81 & 47.66 \\
\hline & 10.0 & 52.81 & 59.50 \\
\hline LSD & & 6.52 & 20.15 \\
\hline
\end{tabular}

The mean $(\mathrm{n}=3)$ difference is significant at $P \leq 0.01$.

Bergé et al., (2002), who found that the sulfolipid compounds extracted from red algal Porphyridium possessed an inhibition effect against MCF-7. In another study carried out by Shao et al., (2002), they found that the sulfolipid compounds ((2R)1-O-myristoyl-2-O-palmitoyl-3-O-(6-sulpho-a-Dquinovo-pyranosyl)-glycerol) from the brown algae Chondria crassicaulis possessed an inhibition effect against HL60 and MCF-7 cell lines. Bhaskar et al., (2004), reported that the total lipid and lipid classes of brown algae S. marginatum have potent inhibition of human pro-melocytic leukemia HL60. Also Hossain et al., (2005) reported that the SQDG of brown algae $S$. horneri showed significant apoptosis activity towards Caco-2 cells. The SQDG fraction obtained from dried spinach was an inhibitor of mammalian DNA polymerases and a growth inhibitor of NUGC3 human gastric cancer cells (Maeda et al., 2005). Sahara et al. (2002) and (Mizushina et al., 2003) found that the synthetic sulfoquinovosyl-mono-acylglycerols had a highly significant effect in suppressing the growth of solid tumors (human lung adenocarcinoma A-549 cells), and showed a potent inhibition of DNA polymerase and potent antineoplastic agents against the gastric cancer cell line (NUGC3).

Antimicrobial activity of algal sulfolipids. Marine algal sulfolipids (SLs) presented a high growth inhibition of the bacterial strains $(B$. subtilis and $E$. coli) at the concentration of $100 \mu \mathrm{g} /$ well, while all algal SLs did not show any inhibition effect against fungal or yeast cells (Table 6). The highest bacterial growth inhibition was obtained by $T$. atomaria sulifolipids $(15.0 \mathrm{~mm})$ against $E$. coli followed by $U$. fasciata sulifolipids $(13 \mathrm{~mm})$ and G. cylindriea sulifolipids $(11 \mathrm{~mm})$. L. papillose 
Table 5

Comparison of marine algal sulfolipid fractions against MCF7 and HepG2

\begin{tabular}{lcc}
\hline \multirow{2}{*}{ Marine algae species } & \multicolumn{2}{c}{$\mathbf{I C}_{50} \mathbf{\mu g ~ m L}^{-1}$} \\
\cline { 2 - 3 } & MCF7 Cell & HepG2 Cell \\
\hline U. fasciata & 0.54 & 1.41 \\
T. atomaria & 0.40 & 0.60 \\
D.fasciola & 0.60 & 0.60 \\
L. papillose & 0.67 & 2.21 \\
G. cylindriea & 0.40 & 2.75 \\
Novantron (reference drug) & 1.4 & 4.0 \\
\hline
\end{tabular}

Table 6

Antimicrobial activities of marine algal Sulfolipids (inhibition zone in diameter $(\mathrm{mm})$ around the discs) and MIC

\begin{tabular}{|c|c|c|c|c|}
\hline \multirow{3}{*}{ Marine algae species } & \multirow{2}{*}{\multicolumn{2}{|c|}{$\begin{array}{c}\text { Inhibition zone (mm) } \\
\text { Microorganisms }\end{array}$}} & \multirow{2}{*}{\multicolumn{2}{|c|}{$\begin{array}{c}\text { MIC } \mu g \mathrm{~mL}^{-1} \\
\text { Microorganisms } \\
\text { Bacteria }\end{array}$}} \\
\hline & & & & \\
\hline & E. coli & B. subtilis & E. coli & B. subtilis \\
\hline U. fasciata & 13.0 & 16.0 & 60.0 & 40.0 \\
\hline T. atomaria & 15.0 & 13.0 & 60.0 & 40.0 \\
\hline D. fasciola & 8.0 & 10.0 & - & - \\
\hline L. papillose & 8.0 & 11.0 & - & - \\
\hline G. cylindriea & 11.0 & 11.0 & 80.0 & 80.0 \\
\hline Chloramphenicol (reference drug) & 15.0 & 18.0 & 25.0 & 20.0 \\
\hline
\end{tabular}

$(8 \mathrm{~mm})$ and $D$. fasciola sulifolipids $(8 \mathrm{~mm})$ showed the lowest growth inhibition against $E$. coli. The maximum inhibition zone against Bacillus subtilis was observed in $U$. fasciata sulifolipids $(16 \mathrm{~mm})$ followed by $T$. atomaria sulfolipids $(13 \mathrm{~mm})$. A moderate inhibition against Bacillus subtilis was observed in G. cylindriea and L. papillose sulfolipids (11 $\mathrm{mm})$, followed by $D$. fasciola sulfolipids $(10 \mathrm{~mm})$. U. fasciata, T. atomaria, L. papillose and $G$. cylindriea algae sulfolipids showed the most potent activity with MIC ranging from 40.0 to 80.0 $\mu \mathrm{g} \mathrm{mL} \mathrm{m}^{-1}$ against $E$. coli and $B$. subtilis. Al-Fadhli et al., (2006) found that the sulfonoglycolipids of the red alga Chondria. armata inhibited the growth of bacteria strains ( $P$. aeruginosa and $K$. pneumoniae) at $20 \mu \mathrm{g} / \mathrm{disc}$, while they have poor activity against the fungi $(A$. fumgatus, $C$. neoformans, $A$. niger and $R$. spp). Sulfoglycerolipids, 1-0-palmitoyl-3$0\left(6^{\prime}\right.$-sulpho- $\alpha$-quinovopyranosyl)-glycerol isolated from the $S$. wightii had antibacterial activity against Xanthomonas oryzae which causes bacterial blight in rice (Arunkumar et al., 2005).

In conclusion, the GC/MS and LC/Ms identified many compounds from extracted algal sulfolipids and two major compounds were identified by ESI/MS fragmentation. The ESI/MS of the major component of algal sulfolipids (SQDM) was a consistent molecular ion $[\mathrm{M}+\mathrm{H}]^{+}$at $\mathrm{m} / \mathrm{z}=$ 820 corresponding to the molecular formula of
$\mathrm{C}_{43} \mathrm{H}_{78} \mathrm{O}_{12} \mathrm{~S}$ and the second compound (SQMG) was the consistent molecular ion $[\mathrm{M}+\mathrm{H}]^{+}$at $\mathrm{m} /$ $z=556.71$ corresponding to the molecular formula of $\mathrm{C}_{25} \mathrm{H}_{48} \mathrm{O}_{11} \mathrm{~S}$. The algal sulfolipid fraction has antitumor activity against (HepG2 and MCF-7 cell lines) and antibacterial activity against Bacillus subtilis and Escherichia coli. The antitumor and antibacterial activities of algal sulfolipids are probably owing to the presence of the sulfolipids as sulfoquinovosyl-di-acylglycerol, sulfoquinovosyl acylglycerol, unsaturated fatty acids and sulfate contents.

\section{REFERENCES}

Al-Fadhli A, Wahidulla S, D'Souza L. 2006. Glycolipids from the red alga Chondria armata (Kütz.) Okamura. Glycobiology 16, 902-915.

Araki S, Sakurai T, Oohusa T, Kayama M, Sato N. 1989. Characterization of sulfoquinovosyl diacylglycerol from marine red algae. Plant Cell Physiol. 30, 775781.

Araki S, Sakurai T, Oohusa T, Kayama M, Nisizawa K. 1990. Content of arachidonic and eicosapentaenoic acids in polar lipids from Gracilaria (Gracilariales, Rhodophyta). Hydrobiologia 204/205, 513-519.

Arunkumar K, Selvapalam N, Rengasamy R. 2005. The antibacterial compound sulphoglycerolipid 1-0 palmitoyl-3-0 (6'-sulpho- $\alpha$-quinovopyranosyl)-glycerol 
from Sargassum wightii Greville (Phaeophyceae). Bot. Mar. 48, 441-445.

Bergé PJ, Debiton E, Dumay J, Duand P, Barthomeuf C. 2002. In vitro anti-inflammatory and anti-proliferative activity of sulfolipids from the red alga Porphyridium cruentum. J. Agric. Food Chem. 50, 6227-6232.

Benning C, Somerville RC. 1992. Isolation and genetic complementation of a sulfolipid-deficient mutant of Rhodobacter sphaeroides. J. Bacteriol. 174, 2352-2360.

Benning C, Garavito RM. 2009. Sulfolipid Biosynthesis and Function in Plants, Rüdiger Hell et al. (Eds.), Sulfur Metabolism in Phototrophic Organisms, 185-200.

Bhaskar N, Hosakawa M, Miyashita K. 2004. Growth inhibition of human pro- myelocytic Leukemia (HL60 ) cells by lipid extracts of marine algae Sargassum marginatum (Fucales, phaeophyta) harvested off Goa (west coast of India) with special reference to fatty acid composition. Indian J. Mar. Sci. 33, 335-360.

Bigogno C. Khozin-Goldberga I, Boussibaa S, Vonshaka A, Cohena Z. 2002. Lipid and fatty acid composition of the green oleaginous alga Parietochloris incisa, the richest plant source of arachidonic acid. Phytochem. 60, 497-503.

Chirasuwan N, Chaiklahan R, Kittakoop P, Chanasattru W, Ruengjitchatchawalya M, Tanticharoen M, Bunnag B. 2009. Anti HSV-1 activity of sulphoquinovosyl diacylglycerol isolated from Spirulina platensis. Sci. Asia 35, 137-141.

De-Souza ML, lacomini M, Gorin AJP, Sari SR, Haddad AM, Sassaki LG. 2007. Glyco- and sphingophosphonolipids from the medusa Phyllorhiza punctata: NMR and ESI-MS/MS fingerprints. Chem. Phys. Lipids 145, 85-96.

Ermanno A, Guido B, Gianguido R, Ronald JW. 1994. FT-IR study of the interaction of magnesium ferrite with $\mathrm{SO}_{2}$. Catal. Lett. 23, 353-360.

Gerasimenko IN, Busarova GN, Moiseenko PO. 2010. Age dependent changes in the content of lipids, fatty acids and pigments in brown alga Costaria costata. Russ. J. Plant Physiol. 57, 62-68.

Gomes KA, Gomes AA. 1984. Statistical procedures for agricultural research. $2^{\text {nd }}$ ed. Jon Willey and Sons Inc, New York, U.S.A.

Greenwood D. 1983. Antimicrobial chemotherapy, Part II-Laboratory Aspects of Antimicrobial Therapy Bailliere, Tindall, London, p. 71.

Gustafson KM, Cardellina JH, Fuller RW, Weislow OS, Kiser RF, Snader KM, Patterson GML. 1989. AIDsantiviral sulfolipid from cynobacteria (blue-green algae). J. Nat. Cancer Inst. 81, 1254-1258.

Hammer KA, Carson CF, Riley TV. 1999. Antimicrobial activity of essential oils and other plant extracts. $J$. Appl. Microbiol. 86, 985-990.

Hossain Z, Kurihara H, Masashi H, Takahashp K. 2005. Growth inhibition and induction of differentiation and apoptosis mediated by sodium butyrate in CACO-2 cells with algal glycolipids. In Vitro Cell. Dev. Biol. Animal 41, 154-159.

Keusgen M, Curtis MJ, Thibault P. 1997. Sulfoquinovosyl diacylglycerols from the alga Heterosigma carterae. Lipids 32, 1101-1112.

Khotimchenko VS. 2002. Distribution of glycoglycerolipids in marine algae and grasses. Chem. Nat. Compd. 38, 223-229.

Khotimchenko VS. 2003. The fatty acid composition of glycolipids of marine macrophytes. Russ. J. Mar. Biol. 29, 126-128.

Liptak A, Balla E, Lorant J, Sajtosa F, Lászl S. 2004. The first synthesis of secondary sugar sulfonic acids by nucleophilic displacement reactions. Tetrahedron Lett. 45, 839-842.

Luddy FE, Beerford RA, Riemen RW. 1960. Direct conversion of lipid component to their fatty acid methyl ester. J. Am. Oil Chem. Soc. 37, 447-451.

Maeda N, Hada T, Murakami-Nakaia C, Kuriyamaa I, Hideki I, Fukumorid Y, Hiratsukaf J, Yoshidaa H, Sakaguchig K, Mizushinaa Y. 2005. Effects of DNA polymerase inhibitory and antitumor activities of lipase-hydrolyzed glycolipid fractions from spinach. J. Nutr. Biochem. 16, 121-128.

Maeda N, Kokai Y, Ohtani S, Sahara H, KumamotoYonezawa Y, Kuriyama I, Hada T, Sato N, Yoshida H, Mizushina Y. 2008. Anti-tumor effect of orally administered spinach glycolipid fraction on implanted cancer cells, colon-26, in mice. Lipids 43, 741-748.

Matanjun P, Mohamed S, Mustapha MN, Muhammad K. 2009. Nutrient content of tropical edible seaweeds, Eucheuma cottonii, Caulerpa lentillifera and Sargassum polycystum. J. Appl. Phycol. 21, 75-80.

Manivannan K, Thirumaran G, Karthikai, Devi G, Hemalatha A, Anantharaman P. 2008. Biochemical composition of seaweeds from Mandapam coastal regions along Southeast Coast of India. AmericanEurasian J. Bot. 1, 32-37.

Mizushina Y, Watanabe I, Ohta K, Takemura M, Sahara H, Takahashi N, Gasa S, Sugawara F, Matsukage A, Yoshida S, Sakaguchi K. 1998. Studies on inhibitors of mammalian DNA polymerase alpha and beta: sulfolipids from a Pteridophyte and Athyrium niponicum. Biochem. Pharmacol. 55, 537-541

Mizushina $\mathrm{Y}$, Maeda $\mathrm{N}$, Kawasaki $M$, Ichikawa $H$, Murakami C, Takemura M, Xu X, Sugawara F, Ukumori Y, Yoshida H, Sakaguchi K.,2003. Inhibitory action of emulsified sulfoquinovosyl acylglycerol on mammalian DNA polymerases. Lipids 38, 1065-1074.

Naumann I. 2009. Sulfoquinovosyldiacylglyceride antiviral active Substanzen. ph.D. Thesis, Fakultät der Universitt Erlangen-Nürnberg.

Norman AH, Mischke FC, Allen B, Vincentt SJ. 1996. Semi-preparative isolation of plant sulfoquinovosyldiacylglycerols by solid phase extraction and HPLC procedures. J. Lipid Res. 37, 1372-1376.

Ohta K, Mizushina Y, Hirata N, Takemure M, Sugawar F, Matsukage A, Yoshida S, Sakaguchi K. 1998. Sulfoquinovosyldiacylglycerol, KM043, a new potent inhibitor of eukaryotic DNA polymerases and HIVreverse transcriptase type1 from a marine red alga. Chem. Pharm. B. 46, 281-291.

Pons A, Timmerman P, Leroy Y, Zanetta JP. 2002. Gas-chromatography/mass-spectrometry analysis of human skin constituents as heptafluorobutyrate derivatives with special reference to long-chain bases. J. Lipid Res. 43, 794-804.

Ranjaniv S, Steven W. 1995. FTIR characterization of the interaction of oxygen with zinc sulfide. Indian Eng. Chem. Res. 34, 699-702.

Roughan PG, Bratt DR. 1968. Quantitative analysis of sulfolipid (sulfoquinovosyl diglyceride) and galactolipids (monogalactosyl and digalactosyl diglycerides) in plant tissue. Anal. Biochem. 22, 74-88.

Sanina MN, Goncharova NS, Kostetsky YE. 2004. Fatty acid composition of individual polar lipid classes from marine macrophytes. Phytochemistry 65, 721-730.

Sahara H, Hanashima S, Yamazak, Takahashi TS, Sugawara F, Ohtani S, Ishikawa M, Mizushina Y, Ohta K, Shimozawa K, Gasa S, Jimbow K, Sakaguchi K, Sato N, Takahashi N. 2002. Anti-tumor effect of 
chemically synthesized sulfolipids based on sea Urchin's natural sulfonoquinovosylmonoacylglycerols. J. Cancer Res. 93, 85-92.

Shao ZY, Cai JN, Ye QZ, Guo YI. 2002. Crassicaulisine, sulphonoglycolipid from red algae Chondria crassicaulis Harv. J. Asian Nat. Prod. Res. 4, 205209.

Skehan P, Storeng R, Scudiero D, Monks A, McMahon J, Vistica D, Warren JT, Bokesch H, Kenney S, Boyd MR. 1990. New colorimetric cytotoxicity assay for anticancer-drug screening. J. National Cancer Inst. 82, 1107-1112.

Simons K, Toomre D. 2000. Lipid rafts and signal transduction. Nat. Rev. Mol. Cell Bio. 1, 31-39.
Tebas P, Stabell EC, Olivo PD. 1995. Antiviral susceptibility testing with a cell line which expresses beta-galactosidase after infection with herpes simplex virus. Antimicrob. Agents Ch. 39, 1287-91.

Terho TT, Hartiala K. 1971. Method for determination of the sulfate content of glycosaminoglycans. Anal. Biochem. 41, 471-476.

Xue C, Hu Y, Saito H, Zhang Z, Li Z, Cai Y, Ou C, Lin H, Imbs AB. 2002. Molecular species composition of glycolipids from Sprirulina platensis. Food Chem. 77, 13.

Recibido: $2 / 5 / 13$ Aceptado: $27 / 8 / 13$ 